\title{
Keeping After-War Goals in View
}

At the opening of her term of office the President of the Association of College and Reference Libraries sends this word to members.

$A^{s}$ WE PROGRESS a little nearer to the end of the war and complete demobilization comes closer, when over two million college people will be freed from military service, we who are associated with college and university and research libraries need to look at our libraries quite critically. What impression will our libraries make on the returning service men and women? Will they live up to the expectations of good service and complete book coverage?

Library buildings and staff are important but they are of little use if they do not supplement a well-selected book collection. The old collection needs to be carefully scrutinized so that deadwood can be discarded. The trend of the educational program of the institution and the interests of the students and faculty must be reflected in the books selected for purchase. The new books about the amazing scientific discoveries of the past few years are important and should be found in every college library. We will want to purchase books concerning the ideologies and customs of the distant parts of the world that our men be- came acquainted with during the war, books that will serve to develop understanding and friendliness between races and nations.

We must not forget our European neighbors whose libraries have been devastated. Our Joint Committee on a Book Campaign for Devastated and Other Libraries in War Areas, under the chairmanship of Milton E. Lord, of the Boston Public Library, is studying the whole question. With the end of the European war all of our libraries can help the foreign universities re-establish their libraries by furnishing valuable publications from among our duplicates.

As we have not been able to have a meeting of the Association of College and Reference Libraries since the Milwaukee meeting in 1942, it would be helpful if we would make more use of College and Research $\mathrm{Li}$ braries as a means of expressing our opinions about matters of interest to us. Various librarians have like problems and are eager to read about methods of solving them. It is our magazine; its pages are open to us; so let us use it.

In the coming year, when times may be trying with shifting staffs and slow commercial services, may we always remember that our object is to promote library service and librarianship of a high standard in spite of difficulties and hindrances. 